\title{
Yield reduction of spring barley in relation to disease development caused by Rhynchosporium secalis
}

\author{
REIJO KARJALAINEN \\ Department of Plant Pathology, University of Helsinki, SF-00710 Helsinki, Finland
}

\begin{abstract}
Effects of barley scald caused by Rhynchosporium secalis on grain yield were studied in three spring barley cultivars under field conditions using artificial inoculation over three years. The disease strongly reduced the green-leaf area duration compared with fungicidetreated leaves. At low infection level, $R$. secalis reduced the grain yield of barley by $3-5 \%$. Moderate and severe infection reduced the grain yields of susceptible cultivars by $10-12 \%$. Single-tiller analysis of yield components indicated that grain weight and ear weight were most affected, but the number of grains was only insignificantly reduced by the disease. Implications of these results for controlling scald disease in Finland are discussed.
\end{abstract}

Index words: Rhynchosporium secalis, spring barley, yield loss

\section{Introduction}

Rhynchosporium secalis (Oud.) Davis, the causal agent of leaf scald, is a serious pathogen of barley in many parts of the world (SHIPTON et al. 1974). When environmental factors favour scald development, yield losses of up to $35-40 \%$ have been reported for spring barley (Schaller 1951, JenKINS and Jemmett 1967, James et al. 1968). Rhynchosporium is heavily dependent on rain and high humidity. The spores are dispersed by rain (Polley 1971, Stedman 1980), and mycelia on dead leaves can produce new spores within $24 \mathrm{~h}$ of wetting, but after drying there is no further sporulation until rewetting occurs (SKoropad 1962). Ryan and Clare
(1975) have shown that, depending on the isolate, the optimal temperature for germ tube production and growth as well as for maximal lesion development immediately following inoculation, is $15-25^{\circ} \mathrm{C}$. Leaf surface wetness for over 14 hours appears to give optimal conditions for lesion and symptom development (Polley 1971, Ryan and Clare 1975). It is interesting, however, that in many barley growing areas $R$. secalis survives between cropping even when it is very hot and there is little rain (MAYFIELD and Clare 1985). For example, in Australia (MAyfield and Clare 1984) $R$. secalis in host debris survives summer temperatures of up to $20^{\circ} \mathrm{C}$ above those 
that usually inhibit spore germination (RYAN and Clare 1975), and the pathogen is subsequently capable of producing inoculum that infects barley. In Finland, I have found that $R$. secalis can easily survive and even grow in barley canopy in rainless and hot summer periods, apparently because the canopy is wet at night, and low light intensity provides a favourable compensation environment for scald development.

In the past twenty years, barley scald disease has become increasingly common in Finland. During that period the barley area in Finland has remarkably increased, and barley cultivation has become more specialized. The increased area and monoculture have at least partly contributed to the recent development of scald disease in Finland. In a disease survey carried out by MÃKELÄ (1974) in 1971-1973 $30 \%$ of the fields were infected by $R$. secalis. However, even though scald seems to be a very important pathogen of barley in cool and wet years, no information is available of its impact on the yield.

The present study was designed to provide information of how $R$. secalis can influence yield and yield components of some commonly grown barley cultivars in Finland. The significance of these results for disease control is discussed.

\section{Materials and methods}

Yield reduction in barley caused by scald disease was studied in three years, 1983, 1985, and 1986. Three cultivars, susceptible Hankkija's Pokko, Ida, and moderately resistant or less susceptible Birger were selected for field tests. Experiments were carried out in a randomized block design with eight replications, half of which were inoculated with $R$. secalis. In 1983, experiment I was designed to study the edge effects of plot on disease induced yield loss. Therefore, $20 \mathrm{~m}^{2}$ plots were used, but only the central part of the plot was used for yield harvesting. In the other experiments, plot size was $10 \mathrm{~m}^{2}$. Normal fertilization levels and herbicide treatments were used.
All inoculated plots were surrounded by oat guard plots to prevent inoculum from spreading into control plots.

Inoculation was carried out by spraying $R$. secalis spore suspension onto test plots. In most cases, mixtures of two or three isolates of $R$. secalis were used. The isolates were collected from various parts of barley area in Finland and cultured on lima bean agar at $16^{\circ} \mathrm{C}$ for 10-14 days for spore production. Spore suspension of about $10^{6}$ spores $/ \mathrm{ml}$ were used for inoculation.

Inoculations were made late in the evening in order to ensure high humidity for disease development. In 1983, inoculations were started at the beginning of flag leaf emergence, at a late stage of barley development. Occasional rains a few days after inoculations enhanced disease development so that only one inoculation was made. In 1985 and 1986, inoculations were started already at the three leaf stage, and three inoculations were made every fifth day.

Disease development was monitored by counting 60 plants per plot and estimating disease containing leaf area on three upper leaves. At the same time, green-leaf area duration was monitored on labelled tillers by visually estimating non-green leaf area because this trait was more accurate to estimate than green-leaf area.

In some cases, fungicide treatments (Bayleton, Tilt) were included in the trials in order to evaluate the effects of fungicides to control scald disease.

Before harvest, the 60 labelled tillers per plot were collected and subjected to yield component analysis. Grain yields and thousand grain weights were analyzed from whole plot data. Analyses of variance were computed from yield data.

\section{Results}

\section{Disease development}

Weather conditions during the growing seasons varied greatly (Table 1). In 1983 the 
Table 1. Monthly mean temperatures and total rainfall in May - August in the years 1983, 1985 (Helsinki-Malmi airport), and 1986 (Helsinki, Kaisaniemi).

\begin{tabular}{llcc}
\hline & $\begin{array}{c}\text { Mean } \\
\text { temperature } \\
{ }^{\circ} \mathrm{C}\end{array}$ & $\begin{array}{c}\text { Rainfall } \\
\mathrm{mm}\end{array}$ \\
\hline 1983 & May & 11.8 & 37.5 \\
& June & 13.9 & 55.3 \\
& July & 18.3 & 23.8 \\
& August & 15.8 & 52.4 \\
1985 & May & 9.4 & 60.5 \\
& June & 13.7 & 66.3 \\
& July & 16.1 & 77.5 \\
& August & 16.3 & 95.4 \\
May & 10.3 & 36.0 \\
& June & 17.0 & 29.0 \\
& July & 17.3 & 82.0 \\
& August & 14.6 & 160.0 \\
\hline
\end{tabular}

weather was dry, and particularly in July the rainfall was exceptionally low. However, at the same time the temperature was higher than in most years, and $R$. secalis infection progressed first moderately, but slowed down towards the end of the growing period (Fig. 1).

In 1985 the weather was favourable for scald development. June and July were cool and rainy, and $R$. secalis progressed rapidly from the lower leaves to the upper parts of the canopy (Fig. 2).

Summer 1986 was exceptional in many respects. It rained very little in June, moderately in July, but both June and July temperatures were high compared with previous years. Low rainfall in June and the high temperatures in June and July apparently delayed the epidemic build-up of $R$. secalis, and several inoculations were needed to induce disease outbreak (Fig. 3).

In all experiments cv. Pokko was more severely infected by $R$. secalis than cv. Birger. Fungicide treatments reduced the disease progress into the canopy (Fig. 1).

Disease-induced green-leaf area destruction was monitored simultaneously with disease severity. The results indicate (Fig. 4) that leaf-area duration was inversely associated with disease progress. Birger appeared to prolong leaf area duration under disease pressure

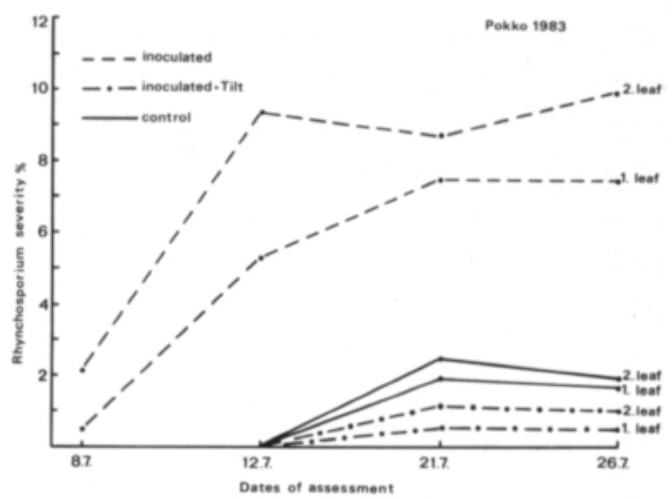

Fig. 1. Development of Rhynchosporium secalis on two upper leaves of cv. Pokko in 1983 under dry weather conditions.

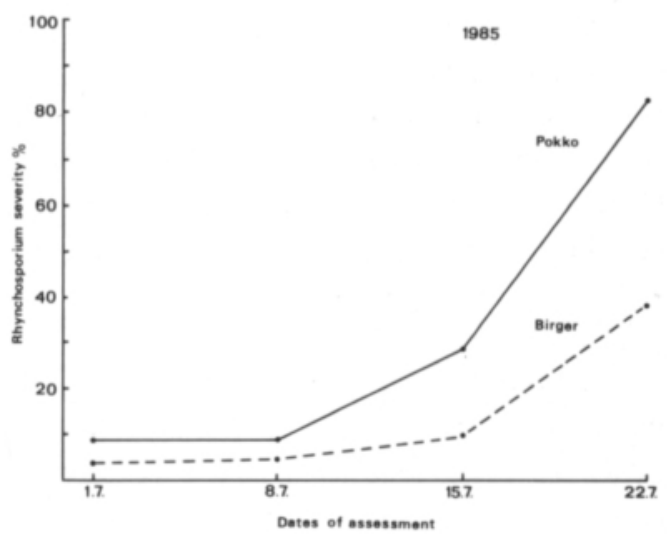

Fig. 2. Development of $R$. secalis on second leaves of cultivars Pokko and Birger in 1985 under favourable weather conditions for disease development.

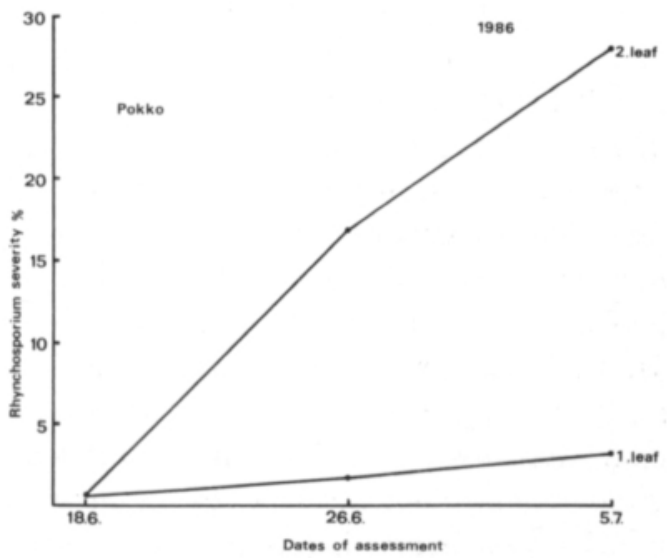

Fig. 3. Development of $R$. secalis on two upper leaves of cv. Pokko in 1986. 


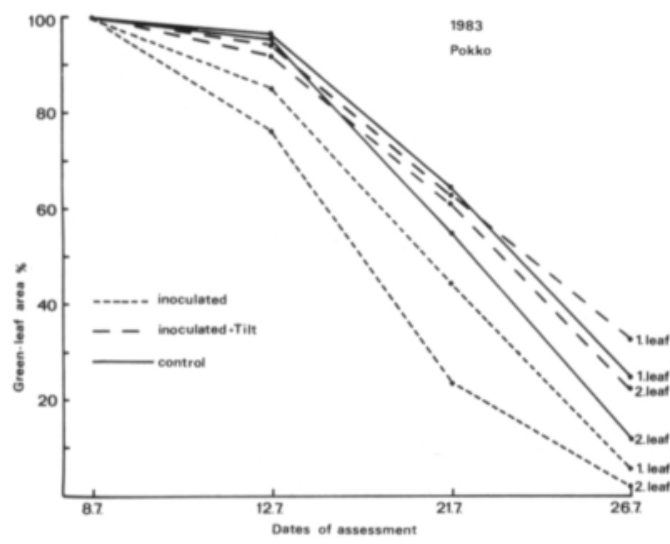

Fig. 4. Green-leaf area duration on two upper leaves of cv. Pokko in 1983 under disease stress caused by $R$. secalis.

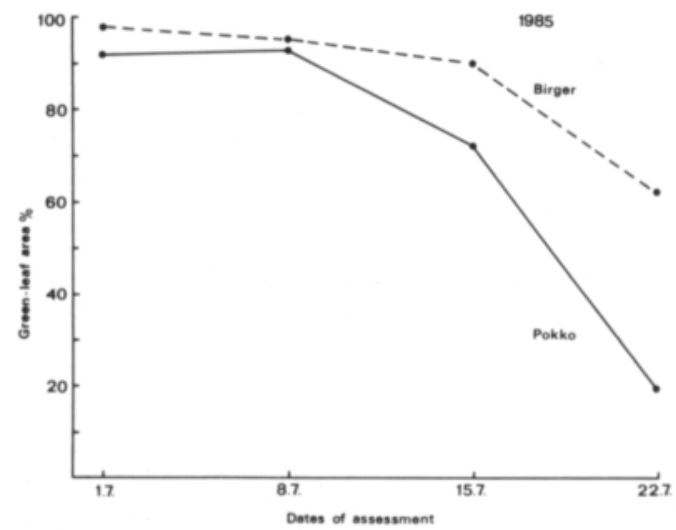

Fig. 5. Green-leaf area duration on second leaves of cultivars Pokko and Birger under disease stress in 1985.

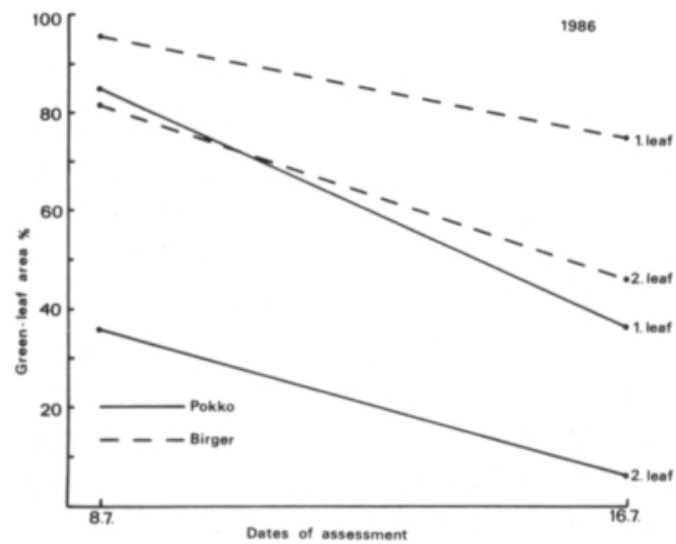

Fig. 6. Green-leaf area duration on two upper leaves of cultivars Pokko and Birger under disease stress in 1986. better than the more susceptible Pokko (Figs $5,6)$. Fungicide treatment delayed the senescence of leaves (Fig. 4). In 1985, the disease reduced green-leaf area more rapidly than in years 1983 and 1986, which was in accordance with the rapid progress of scald under favourable weather (Fig. 2).

\section{Effect of $R$. secalis on grain yield}

Despite the unfavourable weather for scald development in 1983, R. secalis induced 10$11 \%(\mathrm{p}<0.01-0.1)$ yield losses in Pokko in two experiments compared with the untreated control (Table 2). The plot size of experiment I was twice that of experiment II, and only the central part of plot I was harvested and used for yield measurement. In this way the edge effects were considered to be reduced. However, there was only a small difference in yield loss between these two trials.

In 1985, the weather was favourable for a rapid disease build-up, but $R$. secalis did not reduce the grain yield of Pokko more than $12 \%$ (Table 3 ). In the same trial, $R$. secalis did not cause any reduction in the grain yield of Birger. That was interesting because the disease was able to progress in Birger (Fig. 2). In Table 3, the results of Birger are based on two years' combined data (1985-1986) because the number of replications in both years was small.

In 1986 , the weather was not suitable for

Table 2. Effect of R. secalis on grain yield of spring barley cultivar Hankkija's Pokko, in comparison with uninoculated controls in the year 1983.

\begin{tabular}{lcccc}
\hline Treatment & \multicolumn{4}{c}{ Grain yield } \\
\cline { 2 - 5 } & $\begin{array}{c}\mathrm{kg} / \mathrm{ha} \\
\text { Experiment 1 }\end{array}$ & $\begin{array}{c}\text { ratio } \\
\text { Ex/ha }\end{array}$ & $\begin{array}{r}\text { ratio } \\
\text { Experiment 2 }\end{array}$ \\
\hline $\begin{array}{l}\text { Control } \\
\begin{array}{l}\text { Rhynchosporium- } \\
\text { inoculation }\end{array}\end{array}$ & 3753 & 100 & 4856 & 100 \\
\hline $\begin{array}{l}\text { Significance } \\
\text { L.S.D.5\% }\end{array}$ & 3365 & 90 & 4309 & 89 \\
\hline
\end{tabular}

${ }^{*},{ }^{* *}$ significant at $\mathrm{P}<0.05, \mathrm{P}<0.01$ levels respectively. 
Table 3. Effects of $R$. secalis on grain yield of spring barley cultivars Hankkija's Pokko and Birger, in comparison with uninoculated controls in the year 1985 .

\begin{tabular}{lrr}
\hline Treatment & \multicolumn{2}{c}{ Grain yield } \\
\cline { 2 - 3 } & $\mathrm{kg} / \mathrm{ha}$ & ratio \\
\hline Pokko & & \\
Control & 4340 & 100 \\
Rhynchosporium-inoculation & 3807 & 88 \\
\hline Significance & & \\
L.S.D.5\% & & \\
Birger & & 100 \\
Rhynchosporium-inoculation & 4822 & 99 \\
\hline Significance & & \\
L.S.D.5\% & & \\
\hline
\end{tabular}

N.S. = not significant

Table 4. Effects of $R$. secalis on grain yields of spring barley cultivars Hankkija's Pokko and Ida, in comparison with uninoculated controls in the year 1986.

\begin{tabular}{lrr}
\hline Treatment & \multicolumn{2}{c}{ Grain yield } \\
\cline { 2 - 3 } & $\mathrm{kg} / \mathrm{ha}$ & ratio \\
\hline Hankkija's Pokko & & \\
Control & 5156 & 100 \\
Rhynchosporium-inoculation & 4877 & 95 \\
\hline Significance & & \\
L.S.D.5\% & N.S. & \\
Ida & 624 & \\
Control & & \\
Rhynchosporium-inoculation & 4090 & 97 \\
\hline Significance & & \\
L.S.D.5\% & N.S. \\
\hline
\end{tabular}

N.S. = not significant; ${ }^{*}$ significant at $\mathrm{P}<0.05$ level.

rapid disease spread, and $R$. secalis reduced the grain yields of susceptible varieties Pokko and Ida only 5 and $3 \%$, respectively (Table 4).

\section{Effect of $R$. secalis on yield components}

Infection was severe in experimental fields in 1983 and 1986 only at a late stage of barley
Table 5. Effects of $R$. secalis on 1000-grain weights of spring barley cultivars Hankkija's Pokko, Ida, and Birger, in comparison with uninoculated controls in the year 1986.

\begin{tabular}{|c|c|c|}
\hline \multirow[t]{2}{*}{ Treatment } & \multicolumn{2}{|c|}{$1000-g w$} \\
\hline & g & ratio \\
\hline \multicolumn{3}{|l|}{ Hankkija's Pokko } \\
\hline Control & 49.7 & 100 \\
\hline Rhynchosporium-inoculation & 47.3 & 95 \\
\hline Significance & $*$ & \\
\hline L.S.D. $5 \%$ & 2.1 & \\
\hline \multicolumn{3}{|l|}{ Ida } \\
\hline Control & 54.1 & 100 \\
\hline Rhynchosporium-inoculation & 53.6 & 99 \\
\hline Significance & N.S. & \\
\hline L.S.D. $5 \%$ & 1.0 & \\
\hline \multicolumn{3}{|l|}{ Birger } \\
\hline Control & 59.8 & 100 \\
\hline Rhynchosporium-inoculation & 59.7 & 100 \\
\hline Significance & N.S. & \\
\hline L.S.D. $5 \%$ & 6.8 & \\
\hline
\end{tabular}

development, and thus grain weight was the yield component principally affected by the disease. Measurements of thousand grain weights from whole plots in 1986 revealed significant reduction only in the grain weight of Pokko (Table 5), while the susceptible cultivar Ida suffered only slightly. The grain weight of Birger was not affected at all.

Single tillers were taken from the plots for more detailed analyses. The yield component data (Table 6) showed that disease induced significant reductions in the grain weight of Pokko. Grain numbers/ear and ear weights were also reduced but non-significantly. Infection reduced all yield components of Ida, but grain weight and ear weight were significantly reduced (Table 6). The results thus suggest that the grain weight data above, based on samples from whole plots, might be more liable to sample errors than the data based on single tillers. 
Table 6. Effect of $R$. secalis on yield components of spring barley cultivars Hankkija's Pokko and Ida in comparison with uninoculated controls in the year 1986.

\begin{tabular}{|c|c|c|c|}
\hline \multirow[t]{2}{*}{ Treatment } & \multirow{2}{*}{$\begin{array}{l}\text { grains/ } \\
\text { ear }\end{array}$} & \multirow{2}{*}{$\frac{\text { ear weight }}{\mathrm{g}}$} & $1000-\mathrm{gw}$ \\
\hline & & & g ratio \\
\hline \multicolumn{4}{|l|}{ Hankkija's Pokko } \\
\hline Control & 34.8 & 1.31 & 37.3 \\
\hline $\begin{array}{l}\text { Rhynchosporium- } \\
\text { inoculation }\end{array}$ & 32.9 & 1.17 & 35.0 \\
\hline Significance & N.S. & N.S. & $* *$ \\
\hline L.S.D. $5 \%$ & 4.4 & 0.19 & 2.7 \\
\hline \multicolumn{4}{|l|}{ Ida } \\
\hline Control & 16.4 & 0.83 & 50.3 \\
\hline $\begin{array}{l}\text { Rhynchosporium- } \\
\text { inoculation }\end{array}$ & 15.8 & 0.75 & 47.1 \\
\hline Significance & N.S. & $* *$ & $* * *$ \\
\hline L.S.D. $5 \%$ & 0.8 & 0.06 & 1.5 \\
\hline
\end{tabular}

$\mathrm{N} . \mathrm{S}$. = not significant; ${ }^{* *},{ }^{* *}$ significant at $\mathrm{P}<0.01$, $\mathrm{P}<0.001$ levels respectively.

\section{Discussion}

The Finnish climate is favourable for scald disease development. In most years the growing season is cool and wet, and later in summer dew provides humidity inside barley canopy for many hours, which ensures scald survival even in rainless periods. Finnish farming practice also favours the development of scald disease because barley fields are often small and surrounded by forests which keep them humid. Autumns are often wet, which makes effective ploughing difficult with the consequence of abundant debris remaining on soil. $R$. secalis can overwinter in plant debris (Polley 1971) and spread into new barley growth in the next season. This and infected seed are apparently the main sources of its inoculum in Finland. There are some clear indications that the increasing use of CCC to prevent lodging promotes the incidence of $R$. secalis (Shipton et al. 1974), and in southern Finland farmers have increasingly used $\mathrm{CCC}$ in recent years. All these factors and the fact that most currently grown barley cultivars are susceptible to $R$. secalis (KARJALAINEN, unpublished) have contributed to the widescale incidence of scald disease in Finland in the past years.

The results reported here show a yield reduction of $5-12 \%$ in the susceptible cultivar Pokko in relation to untreated control plots. A similar type of experiment was carried out by SKOROPAD (1960), who compared inoculated and fungicide treated plots. $\mathrm{He}$ found $10-12 \%$ yield losses due to induced field epidemics caused by $R$. secalis. In California, Schaller (1963) reported crop losses of up to $35 \%$ using isogenic lines. It is interesting to note that even during the severe epidemic of $1985, R$. secalis induced yield losses of only $12 \%$, whereas under similar disease conditions Septoria nodorum can reduce the yield of susceptible wheats by $20 \%$ (KARJALAINEN 1985). This might be due to the longer growing time of spring wheat in Finland compared to barley, and thus $S$. nodorum has a longer time to affect grain filling of wheat than $R$. secalis of barley.

Our cultivars appear to respond differentially to the disease. Birger, which was also infected but not to such extent as Pokko and Ida, did not seem to suffer any yield losses. It remains to be seen whether this is due to tolerance effect or not. In a previous glasshouse study Rowling and Jones (1976) observed some evidence of tolerance after $R$. secalis infection.

In our study the yield loss of barley was apparently mainly due to disease-induced greenleaf area destruction. Thus the total photosynthetic area was reduced with the consequence that dry matter accumulation into grains was limited. This is in accordance with our observations, which showed that the 1000-grain weight was the main yield component reduced due to infection. In 1983, inoculation was made during flag leaf emergence, and it is known (TENG and GAUNT 1980) that such late inoculation principally reduces grain weight because the other yield components have already been formed. However, in 1986 inocu- 
lation was made immediately at the three-leaf stage and repeated three times. In this experiment all yield components of susceptible Pokko and Ida were affected, but most of all the 1000 -grain weight.

Our results confirm some previous glasshouse and field trials (Rowling and JONES 1976, JACKSON and WeBSTER 1981) where $R$. secalis infection mainly lowered grain weight and the number of grains per ear. There is some evidence (GALlAGHER et al. 1975) that although photosynthesis post-anthesis generally provides the majority of the dry matter in the barley grain, under extreme conditions considerable part of the final grain weight can also be provided by retranslocation. Therefore early infection can also influence the final grain weight.

It is evident that the yield loss caused by $R$. secalis is not accounted for merely by the reduced amount of green-leaf area duration. $R$. secalis is a necrotrophic pathogen influencing the diseased barley plant in several ways. Abnormal stomatal behaviour occurs after the fungus has penetrated into leaves (AYREs 1972, BRANCHARD and LAFFrAY 1987). Increased transpiration of scald infected leaves has also been observed (AYRES and JONES 1975). In addition, $R$. secalis excretes toxic molecules, such as Rhyncosporosidetype compounds (Auriol et al. 1978), which have been found to affect the loss of turgor in young plants. Recently, MARTIN (1986) showed that photosynthesis in barley leaves was reduced mainly at about the time of scald symptom appearance, but reduction was not observed before visible symptoms.

The above experiments show that the scald disease of barley can reduce grain yield by up to $3-12 \%$ under moderate to severe infection conditions. Yield reduction is mainly due to lowered grain weight, which also implies that scald apparently reduces the hectolitre weight. There is large variation in the incidence of scald disease between different years, regions, and fields. The occurrence of scald is not uniform even within a single field, and the spatial distribution of disease units in a pathosystem is the most important factor influencing field estimations of disease and yield loss (TENG 1983). Therefore, it is extremely difficult to predict how much scald can totally reduce Finnish barley yields because extensive field surveys of disease incidence would be required to address this question. JAMES et al. (1968) developed a yield loss — disease severity relationship equation, which based on the observation that there is a linear relationship between yield and the percentage of laminar area affected by leaf blotch on the flag and second leaves at growth stage 11.1. However, more recently it was demonstrated (KHAN and D'AntuONo 1985) that third leaf disease amount correlates best with observed yield loss.

Recent advances in using remote sensing assessment method and their implications (NuTTER and CUNFER 1988) that they may predict yield losses caused by $R$. secalis relatively accurately might give an easier and more effective way to evaluate the national losses of barley crop induced by scald disease. It seems evident that for the past two decades, and even before that (MÄKELÄ 1974), scald has been the major leaf disease of barley of significant economic importance in Finland. The most serious losses have occurred in wet summers when humidity has provided ideal build-up conditions for the disease.

An effective and the economically cheapest form of crop protection is to use disease resistant cultivars (Doodson 1981). There are several barley cultivars and lines possessing major genes for scald disease resistance (WeBster et al. 1980), which can be incorporated into well-adapted barley backgrounds. However, breeding scald-resistant barleys in Finland is still at an early stage, and all cultivars currently grown in Finland are fairly susceptible to the disease (KARJALAINEN, unpublished).

Chemical control of leaf spot diseases of barley is relatively new in Finland, and two fungicides (Bayleton and Tilt) have been used 
to some extent. The present study shows that fungicide treatments clearly prolong the greenleaf area duration with the consequence of increased grain weight compared to the untreated controls. Yield increase due to fungicide treatment in this experiment varied between $5-20 \%$ compared to untreated controls. The current barley prices in Finland imply that the benefit due to fungicide control should be about $250 \mathrm{~kg} / \mathrm{ha}$ or more (KURTTO 1986).

The present study suggests that fungicide treatment is profitable in cool and wet years, when scald reduces yield by $5-10 \%$ or more, but it is unlikely to be profitable in dry, rainless summers. The rational use of fungicides to control scald disease requires a disease monitoring system which allows the right timing of control. Simple forecasting techniques used e.g. for Septoria nodorum monitoring (Tyldesley and ThOMPSON 1980) might prove out to be valuable aids for predicting the optimal time for the control of scald disease because scald is strongly dependent on temperature, the frequency and amount of rain.

\section{References}

Aufhammer, W. von, Kübler, E. \& Stützel, H. 1984. Effekte der Sortenmischung auf die Ertragsbildung von Gerstenbeständen. J. Agronomy \& Crop Science 153: 385-397.

Auriol, P., Strobel, G., Beltran, P.J. \& Gray, G. 1978. Rhynchosporoside, a host-selective toxin produced by Rhyncosporium secalis, causal agent of scald disease of barley. Proc. Natl. Acad. Sci. USA 75: 4339-4343.

Ayres, P.G. 1972. Abnormal behaviour of stomata in barley leaves infected with Rhynchosporium secalis (Oudem.) J. J. Davis. J. Exp. Bot. 23: 683-691.

- \& JonEs, P. 1975. Increased transpiration and the accumulation of root absorbed ${ }^{86} \mathrm{Rb}$ in barley leaves infected by Rhynchosporium secalis (leaf blotch). Physiol. Plant Pathol. 7: 49-58.

Branchard, M. \& Laffray, D. 1987. A porometric comparison between the stomatal behaviour of in vitro cultivated barley plants infected with Rhynchosporium secalis and treated with rhynchosporoside-like toxins. Physiol. Mol. Plant Pathol. 31: 251-260.

Doodson, J.K. 1981. The economic contribution of resistant winter wheat varieties. J. Natn. Inst. Agric. Bot. 15: $413-420$.

Gallagher, J.N., Biscoe, P.V. \& Scott, R.K. 1975. Barley and its environment. V. Stability of grain weight. J. Appl. Ecol. 12: 319-336.

JACKSON, L.F. \& WEBSTER, R.K. 1981. Effects of infection with Rhynchosporium secalis on some components of growth and yield in two barley cultivars. Hilgardia 49: 1-14.

James, W.C., Jenkins, J.E.E. \& Jemmett, J.L. 1968. The relationship between leaf blotch caused by Rhynchosporium secalis and losses in grain yield of spring barley. Ann. Appl. Biol. 62: 273-288.

Jeger, M.J., Griffiths, E. \& Jones, D.G. 1981. Disease progress of non-specialised fungal pathogens in in-

traspecific mixed stands of cereal cultivars. I. Models. Ann. Appl. Biol. 98: 187-198.

Jenkins, J.E.E. \& Jemmett, J.L. 1967. Barley leaf blotch. NAAS O. Rev. 75: 127-132.

Karjalainen, R. 1985. Host-pathogen interaction between spring wheat and Septoria nodorum with reference to resistance breeding. J. Agric. Sci. Finl. 57: $1-66$.

- 1987. Effect of cereal cultivar mixtures on the epidemic development of necrotrophic leaf pathogens. Växtskyddsrapporter, Jordbruk 21-28.

- \& Hıvola, S-L. 1987. Performance of cultivar mixtures under northern growing conditions in Finland. Barley Genetics V, ed. Yasuda, S. \& Konishi, T. p. 719-725. Sanyo Press, Okayama.

Khan, T.N. \& D'Antuono, M.F. 1985. Relationship between scald (Rhynchosporium secalis) and losses in grain yield of barley in western Australia. Aust. J. Agric. Res. 36: 655-661.

KurtTo, J. 1986. Milloin viljojen lehtilaikkutautien torjunta kannattaa. Koetoim. ja Käyt. 43, 24.6.1986.

MARTIN, P.J. 1986. Gaseous exchange studies of barley leaves infected with Rhynchosporium secalis (Oudem) J. J. Davis. Physiol. Mol. Plant Pathol. 28: 3-14.

Mayfield, A.H. \& Clare, B.G. 1984. Survival over summer of Rhynchosporium secalis (barley leaf blotch). Trans. Br. Mycol. Soc. 60: 273-282.

- \& Clare, B.G. 1985. Effects of high temperatures on scald lesion development and sporulation in barley infected with Rhynchosporium secalis. Aust. J. Agric. Res. 36: 197-200.

McDonald, B.A., Allard, R.W. \& Webster, R.K. 1988. Responses of two-, three-, and four-component barley mixtures to a variable pathogen population. Crop. Sci. 28: 447-452.

Mundt, C.C. \& Leonard, K.J. 1986. Analysis of factors affecting disease increase and spread in mixtures of 
immune and susceptible plants in computer-simulated epidemics. Phytopathol. 76: 832-840.

MÄKELÃ, K. 1974. Occurrence of Rhynchosporium secalis (Oud.) J. J. Davis on spring barley and winter rye in Finland. J. Agric. Soc. Finl. 46: 103-117.

Nutter, F.V., Jr. \& Cunfer, B.M. 1988. Quantification of barley yield losses caused by Rhynchosporium secalis using visual versus remote sensing assessment methods. Abstract, 1988 Annual meeting of the American Phytopathological Society, November 13-17, 1988, San Diego, USA.

Polley, R.W. 1971. Barley leaf blotch epidemics in relation to weather conditions with observations on the overwintering of the disease on barley debris. Plant Pathol. 20: 184-190.

Rowling, R.H.D. \& Jones, D.G. 1976. The reaction of three spring barley varieties exposed to epidemics of Rhynchosporium secalis of varying intensity and duration. J. Agric. Sci., Camb. 87: 643-647.

Ryan, C.C. \& Clare, B.G. 1975. Effects of light, temperature and period of leaf-surface wetness on infection of barley by Rhynchosporium secalis. Physiol. Plant Pathol. 6: 93-103.

Schaller, C.W. 1951. The effect of mildew and scald infection on yield and quality of barley. Agronomy J. 43: 183-188.

- 1963. The effect of mildew and scald infection on yield and quality of barley. Agron. J. 43: 183.

\section{SELOSTUS}

\section{Rengaslaikkutaudin vaikutus ohran sadontuottoon}

\section{Reijo Karjalainen}

Kasvipatologian laitos

Helsingin yliopisto, $00710 \mathrm{Helsinki}$

Tässả tutkimuksessa selvitettiin rerngaslaikkutaudin (Rhynchosporium secalis) vaikutusta kahden alttiin (Pokko, Ida) ja yhden kohtalaisesti tautia kestävän (Birger) ohralajikkeen satoon ja eräisiin satokomponentteihin. Kokeet tehtiin Helsingin yliopiston Viikin koetilalla vuosina 1983, 1985 ja 1986. Olosuhteet taudin leviämiselle vaihtelivat vuosittain. Taudin kehitystă seurattiin lehtianalyyseillă arvioimalla ylimpien lehtien tautisuusindeksi ja vihreăn lehtialan kesto. Sadonkorjuun jälkeen laskettiin jyväsato ja 1000-jyvän paino. Lisăksi määritettiin Pokon ja Idan satokomponentit.

Rengaslaikku on viileiden ja sateisten kesien tauti, ja siksi vuosina 1983 ja 1986, jolloin oli lämmintä ja kui-
Shipton, W.A., Boyd, W.J.R. \& Alı, S.M. 1974. Scald of barley. Rev. Plant Pathol. 53: 839-861.

SKoropad, W.P. 1960. Barley scald in the Prairie provinces of Canada. Commonw. Phytopath. News 6: $25-27$.

- 1962. Effect of alternate wetting and drying on sporulation and survival of Rhynchosporium secalis. Phytopathol. 52: 752.

Stedman, O.J. 1980. Observations on the production and dispersal of spores, and infection by Rhynchosporium secalis. Ann. Appl. Biol. 95: 163-175.

TENG, P.S. 1983. Estimating and interpreting disease intensity and loss in commercial fields. Phytopathol. 73: $1587-1590$.

- \& GAUNT, R.E. 1980-81. Modelling systems of disease and yield loss in cereals. Agricultural Systems 6: $131-154$.

Tyldesley, J.B. \& Thompson, N. 1980. Forecasting Septoria nodorum on winter wheat in England and Wales. Plant Pathol. 29: 9-20.

Webster, R.K., Jackson, L.F. \& Schaller, C.W. 1980. Sources of resistance in barley to Rhynchosporium secalis. Plant Dis. 64: 88-90.

WolfE, M.S. 1985. The current status and prospects of multiline cultivars and variety mixtures for disease resistance. Ann. Rev. Phytopathol. 23: 251-273.

Ms received October 6, 1989 vaa, se levisi kasvustossa hitaasti. Vuonna 1983 tauti alensi kahdessa kokeessa Pokon jyvăsatoa $10-11 \%$ ja vuonna 1986 Pokon satoa $5 \%$ ja Idan $3 \%$. Vuonna 1985 kasvukausi oli sateinen ja viileä, ja tauti levisi aikaisin ohrakasvuston yläosiin ja aiheutti Pokolle $12 \%$ satotappion. Tauti alensi huomattavasti yksilöpuitujen tăhkien jyvăn painoa ja koko tăhkän painoa muttei merkittävästi jyvien lukumääräă tăhkissă.

Rengaslaikkutauti lyhensi voimakkaasti ohran lehtialan kestoa, jolloin yhteyttävă kokonaispinta-ala pieneni ja jyvăn kuiva-aineen muodostus văheni. Tămän seurauksena jyvien koko pieneni. Tilt-käsittely hidasti tehokkaasti taudin kehitystä ja piti lehdet vihreănả pidempảän. 
Lippulehden kehittymisen jälkeen tehty Tilt-käsittely paransi eri kokeissa jyväsatoa $5-20 \%$. Tulokset viittaavat siihen, että taudin torjunta kannattaa sadevuosina, jolloin patogeenipopulaation kehitys voidaan pysäyttää oikein ajoitetulla torjuntakäsittelyllă ja siten estäă lehtien ennenaikainen kuihtuminen. Sen sijaan poutavuosina taudin kehitys kasvustossa on hidasta, eikä torjunta useimmiten kannata. 